attention, both from the point of view of using the results in educating local or national opinion and from that of training personnel. Notes on the more important recent surveys are included.

\section{Air Raid Defence}

Is the June number of Air Raid Defence the nature of the air threat is critically examined, in cluding the factor of increased numbers of aircraft, the costs involved, the method of attack and the functions of the incendiary bomb and the gas bomb, as well as of the high explosivo bomb; which is considered to be the main weapon of attack. London is regarded as the most probable target in the lightning attack, although key strategic points such as the steel-making district of Sheffield might also become main targets. Civil defence, it is emphasized, differs entirely from traditional defensive strategy in which the war effort is developed as the war progresses in that the maximum demand will be made of it on the very day that war breaks out. Our organization must be ready to operate effectively immediately peace is despaired of, not a few weeks, or even a few days after war has begun. Moreover, since the lightning attacks are only likely to be delivered for a few weeks, short-term measures aro entirely justifiablo in our main civil defence schemo. It is wrong to plan on the assumption that the intense pressure of the initial blows can bo maintained by the enemy throughout a long war. The parrying of the lightning blow is a problem of imperial strategy; the strategic defence aimis at giving the best protection where it is most required. Wo have hitherto been too much inclined to treat civil defence as a matter for local authorities, with their local responsibilities. What is required is not something for overybody, but a great deal for those who are most likely to be attacked.

\section{Rabbit Control by Virus Infection}

Disappointsient has attended the latest experimental work of the Australian Council for Scientific and Industrial Research on myxomatosis virus as a means of destroying rabbit populations in the field. On Wardang Island, off the coast of South Australia, a colony of about one thousand adults and as many young, in thirty-three warrens, was built up in a ninety-acre enclosure. The disease was introduced into about half tho warrens, and in a hundred days some eight hundred infected animals were collected. Very few warrens not deliberately infected became contaminated. The end result; when the disease had practically disappeared, was almost inappreciable, the death-rate being balanced by the birth-rate. It appears that a sick rabbit leaves its colony, wanders aimlessly away and lives only two to four days. It therefore has little opportunity for infecting other rabbits in its colony, and probably none of giving the disease to other colonies. Thus, although the virus is very virulent indeed, and maintains its toxicity, and although there is no evidence of development of immunity, its capacity to kill off a rabbit population is defeated by the instinctive behaviour of the animal. An insect vector is a possibility that is being explored, though without much hope of success.

\section{Science Review Broadcast}

Tre British Broadcasting Corporation has decided to continue its fortnightly "Science Review", which was begun in January this year. These programmes provide a service of first-hand news from the world of science in a form that is assimilable by the interested layman, and it has the unique advantage of bringing the man of science, whether he is describing a piece of his own research or explaining the significance of an announcement from abroad, into direct contact with his public; and ho need fear no falso emphasis nor misrepresentation because it is ho who does the talk. ing. The programmes last twenty minutes and are usually made up of two separate items, ono of which is selected from the physical or mechanical sciences and the other from the natural sciences. In this way they cater for as wide an audience as possible. Some of the more outstanding talks so far have been Dr. B. A. IKeen's "What Happens to the Rain" (following on one of the wettest weeks in January and his own presidential address to the Royal Meteorological Society); Dr. P. I. Dee's description of the splitting of atoms of uranium; Dr. E. I. White's talk on the South African 'fossil' Colocanth; Dr. Maurice Burton's "Recent Sponge Epidemic in the West Indies"; Donald Carmichael's "How Eskimos Think", and periodic talks on various topical aspects of astronomy by Dr. IV. H. Steavenson. If this programme is to retain the standard of interest and topicality it has succeeded in maintaining so far, it must continue to be largely dependent on the co-operation of scientific workers, who are invited to offer suggestions for suitable subjects.

\section{The Science Museum: Acquisitions}

A SERIEs of interesting transparencies, illustrating recent work of the National Physical Laboratory, on such problems as the accurate measurement of precise components, the determination of the temperature and the pressure of the atmosphere and the speed and direction of the wind during the ascent of a radio-sounding balloon, and recent research in metallurgy, has been set up in the Mruseum. Photographs of John Fitch's Steamboat Model (1785) have been presented by G. H. Eckhardt, of Philadelphia. John Fitch, of Windsor, Connecticut, is said to have first conceived the idea of marine steam propulsion in April 1785. The steamboat model shown was the first mado by him, and was laid before the American Philosophical Society, at Philadelphia, on September 27,1785 . The steamboat was to have been propelled by an endless paddle-chain, which is shown fitted on the port side of the model; on the opposite side is a lee-board. There is no record that such a steamboat was ever tried experimentally: A print of tho P.S. Sarannah (1818) has been presented by the United States National IIuscum. The Sarannah, the first vessel fitted with auxiliary steam propulsion to cross the Atlantic, was a three-masted carvel-built ship of 350 tons burden. To aid her spread of sail, 